\title{
Comparison of the values of potential evapotranspiration estimated through different methods and their relationship
}

USHA DURGAM AND A.S.R.A.S. SASTRI

\author{
Article Chronicle : \\ Received: \\ 27.08.2014; \\ Accepted : \\ 13.05.2015
}

Key Words :

Evapotranspiration, FAO penman,

Open pan method

\begin{abstract}
In the present study, six empirical methods, namely, Modified Penman, Blaney Criddle, Christiansen, Thornthwaite, Open pan, Turc and FAO penman method are computed using the daily weather data for the period 1981-2012 (32 years) was collected for three stations in Chhattisgarh state representing 3 agroclimatic zones. It is found that FAO Penman method is the best method for estimating potential evapotranspiration. The comparison of ETo estimates was done based on the weekly averages of PET using correlation co-efficients and regression methods through different methods. At Ambikapur the highest correlation co-efficient between FAO Penman and Modified Penman method 0.998 and lowest in between Christiansen and Blaney criddle method 0.918. At Jagdalpur and Raipur also having the highest correlation co-efficient between FAO penman and Modified penman method 0.999 and lowest correlation co-efficient in between Christiansen and Turc method 0.85 or 0.84. Regarding regression with Open pan evaporation, highest $\mathrm{R}^{2}$ values are with Modified Penman and Christiansen methods at Ambikapur while at Jagdalpur and Raipur highest $\mathrm{R}^{2}$ was with Christiansen method. Thus, the open pan evaporation can be estimated by Christiansen method.
\end{abstract}

How to CiTE THIS ARTICLE : Durgam, Usha and Sastri, A.S.R.A.S. (2015). Comparison of the values of potential evapotranspiration estimated through different methods and their relationship. Asian J. Environ. Sci., 10(1): 68-75.

Author for correspondence :

\section{USHA DURGAM}

Department of

Agrometeorology, Indira Gandhi Krishi

Vishwavidyalaya, RAIPUR (C.G.) INDIA

See end of the article for

Coopted authors' 